\title{
Élmény és emlékezet: helyzetek és lehetóségek a protestáns iskolákban
}

\author{
Czeglédi SÁndor \\ Károli Gáspár Református Egyetem Neveléstudományi Központ
}

\begin{abstract}
2017-ben a reformáció 500. évfordulóján előadások, tanulmányok sokaságában kerül terítékre a protestantizmus jelentősége, ezen belül az is, hogy mit adtak a protestáns iskolák a magyar múvelődésnek. Jelen tanulmányt ebbe a sorba lehet illeszteni. Írásomban az egyházi iskolákra jellemző sajátos nevelési helyzeteket elemzem. Tanulmányomban a protestáns szó szerepel, de elsősorban református szempontból tekintem át a témát, habár a probléma részben evangélikus közegben is releváns.
\end{abstract}

\section{HAGYOMÁNY ÉS EMLÉKEZET}

Ha a református sajátosságokra gondolunk, akkor lehet, hogy először a református templom jut eszünkbe. Falai fehérek, a szószéknek van központi helye. Az istentisztelet fontos eleme a prédikáció és a zsoltárok éneklése; méghozzá Szenczi Molnár Albert XVII. századi fordításában. De arra is gondolhatunk, hogy a reformátusok (és az evangélikusok is) a keresztyén szót használják a keresztény helyett. A szimbólumok világában pedig szóba jöhet, hogy a magyar reformátusok nem használják a keresztet, nem térdelnek le imádkozás közben.

A református iskola kapcsán Móricz Zsigmond Légy jó mindhalálig címú regénye jut sokaknak eszébe, a tájékozottabbak Szabó Magda írásaira, mindenekelőtt az Abigél-re gondolhatnak. Ezekből a könyvekből a szigorú, fegyelmező iskola képe rajzolódik ki. A légkört áthatja a rendezett életmódra, megszilárdult erkölcsi elvekre törekvés. Ezek a sajátosságok adják a református hagyományok elemeit. Ez a hagyomány stabilitást sugall.

Ha a hagyomány mibenlétét vizsgáljuk, akkor a felhasználható forrásokról is szólnunk kell. Hayden White egyik tanulságos gondolata, hogy a XIX. századi francia társadalomtörténetet könnyebben meg lehet ismerni Balzac regényeiből, mint történészek kutatásaiból. White így ír erről: „a szövegek [pl. egy történész tanulmánya és egy regény - C. S.] mint «egymással versengő elbeszélések» a "cselekményesités» különböző módjai szempontjából szembesítendők egymással" (White, 1997. 256. o.). Ez lehetőséget ad arra, hogy témánk feldolgozásához a visszaemléke- 
zéseken kívül felhasználjuk az irodalmi alkotásokat, így akár az előbb említett regényeket is.Az európai történettudományban a XX. század utolsó harmadában lett kiemelkedő jelentőségú az emlékezetkutatás. Elsősorban Pierre Nora és Jan Assmann munkásságának van nagy hatása. Pierre Nora az emlékezet konstruált voltára hívja fel a figyelmet: Franciaország történelmének példáin mutatja be, hogy társadalmi konfliktusok és időről időre színre lépő szellemi áramlatok más-más szemléletét adják egy közösség múltjának. Így a francia nemzeti identitás is átalakul mindezek során (Nora, 2010. 13-27. o., 290-293. o.). Jan Assmann főleg ókori keleti példákon (az ókori Izráel példáján, az Ószövetségen keresztül) érzékelteti az emlékezet és a történettudomány különbségét. Az emlékezet egy közösség alkotása: „csak a jelentőségteli múltra emlékezünk és csak az emlékezetben tartott múlt múlik el jelentőséggel" (Assmann, 2004, 77. o.). A jelentőséget adott kor értelmisége vagy vezető csoportja fogalmazza meg, s igyekszik szemléletét a közösséggel elfogadtatni.

\section{HAGYOMÁNY ÉS FEGYELEM}

Érvényesek-e a gondolatok a hazai protestáns világban is? A válaszhoz a hagyomány elemeinek átalakulását érdemes figyelnünk. Ha visszatérünk a példáinkra, a templom képe változáson ment keresztül. A XVI. században lemeszelték a templomok középkori freskóit és növényi ornamentikát festettek a fehér felületre. A XVIII. század végétől viszont előtérbe került az a szemlélet, hogy a templom falainak teljesen fehérnek kell lenniük; így a legtöbb helyen a növényi díszítés is eltûnt. ${ }^{1}$ Szokásba jött a kazettás famennyezet, s a mennyezet mintáit a templom központi terében az úrasztala, a szószék és a padok oldalára is felfestették. Számtalan ilyen templom épült, de a XIX. században egyes helyeken a lelkész biztatására lemeszelték ezt a díszítést - ahol könnyen elérhető volt -, nehogy „,ezek nézegetése elvonja a figyelmet a prédikációról”. Más helyen a templom bővítése miatt szabadultak meg a festett kazettáktól-bútoroktól. ${ }^{2}$

Az iskola világára áttérve köztudott, hogy a XVI. században a reformáció terjedése idején alakultak az első protestáns kollégiumok (például a debreceni református kollégium). A XVII. század közepétől az ellenreformáció terjedésével több kollégium üldöztetést élt át, válságos helyzetbe került. A leghíresebb a sárospataki református kollégium sorsa: Báthory Zsófia rekatolizációja után az addig bőkezú patrónus Rákóczi família nem érezte magáénak az intézményt. Erdélyben az 1657-1664 közötti háborús időszak, majd a Rákóczi-szabadságharc idején a labancok támadásai okoztak szorult helyzetet. A XVIII. században, a csendes ellenreformáció idején egészen II. József türelmi rendeletéig szintén sok joghátrány érte kollégiumainkat, a legsúlyosabb a pápai kollégium elüldözése

\footnotetext{
${ }^{1}$ A freskók lefestésére, növényi ornamentika festésére majd annak fehérre festésére példa lehet a Bereg megyei Csaroda református temploma

2 Pl. a hódmezővásárhelyi Ótemplomban az 1870-es években a bútorok egy részét szürkére festették, majd a századfordulón a templom teljes belső berendezését eltávolították.
} 
volt. Csak a határozott védekezés, az iskolákhoz való ragaszkodás segíthetett. Nem véletlen, hogy erős maradt a katolikus egyházzal szembeni gyanakvás. A gyanakvást bezárkózás kísérte.

Bitskey István a Debreceni Református Kollégium Nagykönyvtárában vizsgálta a XVII. századi katolikus szerzők könyveihez írt margináliákat. Szerinte „a konfesszionális kötödés által megszabott alapállás eleve meghatározta a befogadó viszonyát az olvasott szöveghez. Töprengésnek, kérdések megfogalmazásának, dilemmák jelzésének, azaz valódi dialógusnak, eszmecserének nyoma sincs itt; a szerzó és az olvasó egyaránt apologetikus pozíciót foglalt el. A hitvitázó irásoknak ezért egyik fontos funkciójaként az önigazolást, az önreprezentációt jelölhetjük meg. Jórészt a saját álláspont minél pontosabb megfogalmazására törekvő identitásképző szövegeknek minősithetők, mintsem meggyöző érvelésükkel hatást elérő, a vitapartnerek nézeteit alapvetően befolyásoló szellemi fegyvereknek." (Bitskey, 2007. 479. o.).

A szerző szerint érdemes lenne folytatni a kutatást, mert elképzelhető, hogy a fordítottjára, tehát a valódi dialógusra is van példa. A korszak nevelésének másik, hosszan továbbélő eleme a fegyelem, ami jellemzője volt a katolikus nevelésügynek is; s ezt a témát is érdemes lenne kutatni. A fogalom jelenti egyrészt az iskolai, leginkább órai fegyelmet. Közismert, hogy ennek érdekében a testi fenyítés is bevett módszernek számított. A templomban is volt fegyelmezés: a békéscsabai evangélikus nagytemplom felső karzatán, ahol a diákok ültek, máig láthatóak a padokban kifaragott lukak, ahová a pedellusok a pálcájukat szúrták. Innen vették ki, ha a rossz gyereket figyelemre és fegyelemre akarták bírni.

Szabó Magda szerint viszont a debreceni Kossuth utcai templomban, ahová ők az iskolával átvonultak, nem volt felügyelő. Visszaemlékezése szerint „Agancsos barátnőm a templomban az egyenkalap alatt csavarta szőke haját gumivillába, én körömlakkot vittem a padba, és halálmegvető bátorsággal figyeltem, hogy kanyarog a lakkszag a lassú zsoltárdallam mellé, máskor meg még a miatyánk előtt kilógtunk konvojszerüen a Kossuth utcai templom hátsó oldalán, hogy elérjük a moziban az olcsó diákelőadást" (Szabó, 1980.).

A fegyelem másik aspektusa a fegyelmezett gondolkodás volt: a fogalmak pontos ismerete és használata, az olvasott szöveg tartalmának alapos megértése. A fegyelmezett gondolkodás egyik sarokkövének számított a latin nyelv rendszeres tanulása és használata. A nyelvtani szabályokat fiatalon, körülbelül 10-12 éves korban nagyon alaposan megtanulták, a kivételekkel együtt. Sajnos a latinnak „buktatótárgy” szerep is jutott: aki az említett 10-12 éves korban nem tudta az elvárt szinten tanulni, annak ott kellett hagyni a gimnáziumot.

\section{TANÁRI PROFESSZIONALIZÁCIÓ}

A fegyelmezett gondolkodáshoz a XIX. század közepétől-utolsó harmadától új helyzet társult: a tanári professzionalizáció. Néhány évtizedig egymás mellett tanítottak az idősebb generációból származó, általában lelkész képesítésû, pedagógiai stúdiumokat nem végzett tanárok és a fiatalabb, szakszerú diszciplináris 
képzéssel és pedagógiai ismeretekkel felvértezett szakemberek. Hogyan látták őket a korabeli diákok? Érzékelték-e azt a többlet-tudást, amit a professzionalizáció jelentett (vö. Németh, 2004. 181-244. o.)?

A válaszra Hayden White-tól vezérelve nézzünk bele először Móricz Légy jó mindhalálig címú regényébe! Móricz (1921) említi, hogy vannak szakképzett és szakképzetlen tanárok s a szakképzetlenek valahogy szimpatikusabbak. A tanári munka hatékonysága általában alacsony. Előbb néhány példa a szakképzetlenekre. Szúts Istók tornatanár „papnak készült, de rendes szokás szerint hamarabb házasodott, mint állása lett volna, s mivel a kollégium dísze volt tizenkét esztendőn át, megválasztották az öreg Zábráczky professzor nyugdijba vonulása után tornatanárnak. Az öreg Zábráczky tudniillik szépirást és tornát tanított, mert ehhez a két tantárgyhoz nem kellett semmi képesítés, sem képesség: "o még a régi világ embere volt [...] egy régi püspöknek a teremtménye" (Móricz, 1921. 157. o.).

Hasonló volt a magyartanár: "A magyart egy fiatal segédtanár tanitotta, akinek már megjelent egy-két verse egy budapesti lapban, s mindenki azt mondta róla, hogy rém nagy költő. Tulajdonképp esküdtfelügyelö volt, vagyis végzett teológus, aki néhány órát tanított a gimnáziumban, s felïgyelt a bentlakósokra. Ez a tanár fiatal volt, még semmi bajusza se volt, de már olyan szórakozott ember volt, amilyet sose látott életében, akárhányszor egészen összevissza szavakat mondott, s mindjárt elpirult, aztán olyan ijedten nézett körül, mint egy megijesztett kiskutya" (Móricz, 1921. 30. o.). A matematikatanár viszont „egy ideges, kemény legény volt, agyagsárga, lobogó haja volt, s felfelé törülve viselte, szigorú, villámló szeme volt, s kemény ökle. [...] Vőlegény volt, s úgy csapkodta a krétát a táblához, hogy pattogott, néha az ötödik padban ülőknek is majd kiverte a szemét a krétadarab. Nem is sokat törődött a számtannal, eszében sem volt, hogy a számtan törvényeit megfigyeltesse, megértesse, megszerettesse, hogy a gyermeki lelkeket felnyissa, mint a drága kis kapukat a tudás számára; hanem abban a pillanatban, mikor egy gyerek csukott szemekkel állott a törtszámok elött, kitört rajta a düh: «Még ennyit se tudsz, te szamár!» - s zengett a négy fal." (Móricz, 1921. 27. o.).

Ez a jellemrajz akár Karácsony Sándortól is származhatott volna. A regénybeli földrajztanárnál viszont a színvonalas szaktudás és a szórakozottság elemei keverednek, ő az, akit valóban szeretettel ábrázolt Móricz. Móricz a vallástanárról sincs jó véleménnyel, de egyéniségének pozitív oldalát is említi: „a vallástanár, Valkai tanár úr, nem volt emberevő, szépen kisegitette a felelettel a gyereket: ugye, ez volt... s elmondta a leckét, annak csak éppen rá kellett mondani, hogy igen vagy nem... És aztán lehetetlenség volt, hogy valaha egy gyerek nemet mondott volna, mikor igent kellett mondani, mert Valkai tanár úr úgy kérdezett, hogy: "Ugye Jákóbnak tizenkét fia volt? - Nagyon jól van»." (Móricz, 1921. 28. o.).

Ugyanakkor "Misi még késö öregkorában is visszaemlékezett ezeknek az óráknak az unalmára: mert ez az áldott jó ember oly halálos közönnyel foglalkozott a tananyaggal, mintha kukoricát morzsolt volna szakmányba. Később a kisdiák kereste, hogy hol találta meg legelőször életében a természetfölötti dolgokra való gondolást, de olyankor sohasem jutott eszébe sem Valkai tanár úr, sem a többi vallástanár. Az édesanyja jutott eszébe". (Móricz, 1921. 28-29. o.) - s itt érdemes arra gondolnunk, hogy az író édesanyja 
református lelkész gyermeke volt.

De a regényben néhány sorral később Móricz egyértelmúen rosszra értékeli a református hitoktatást: "mikor a hittanórákra gondolt, fáradtság lepte meg és unalom, hatodikban fekete pápaszemet kellett viselnie, mert fájt a szeme; akkor mindig aludt a vallásórán, mert soha olyan vallástanárral nem tudott találkozni, aki e legiszonyúbb és legizgatóbb dolgok tárgyalásánál képes lett volna gyermeklelkét megrezdíteni."

Móricz hittanórai élményeit tehát a tanár közönye és a diákok unalma határozta meg. A regény szerint istenélményét édesanyjának köszönheti, akivel éjjel a csillagokat és a bogarakat nézve jutottak el a Teremtőhöz: „ki csinálta, $k i$ csinálta, ki találta ki... Van... de miért van... meddig van... mi lesz aztán... mi volt azelött... Mikor ezekre gondolt, mindig összegubbaszkodott egészen kicsire, s a térdét átfonta a karjával, mint azokon a csillagos éjszakákon... s ez volt az ő vallása..." (Móricz, 1921. 29. o.).

Ezek alapján az otthonról hozott hatásoknak köszönhető, hogy miután Móricz három helyet (Debrecen, Sárospatak, Kisújszállás) bejárva leérettségizett, mégis a református teológiára jelentkezett, de csak két évig járt oda. Természetesen egyetlen író emlékei csak adalékot szolgáltatnak a vallásoktatáshoz, de 1945 előtt maturált öregdiákokkal beszélgetve több hasonló vélekedéssel találkoztam.

A vallás iránti egyre erősödő közöny a két világháború közötti teológiai irodalomban is visszatérő téma. Bár a kutatás elején vagyok, de ebben a forráscsoportban eddig nem találkoztam azzal a felvetéssel, hogy a közönyhöz a hittanórák is hozzájárulhattak. Karácsony Sándor említ egy vallástanárok körében végzett kutatást. Ebben azt vizsgálták, miért vannak problémák a vallásoktatásban. A kutatás eredménye szerint egyiküknél sem volt önreflexió, mindenki valamilyen külső körülményt tartott felelősnek (Karácsony, 2004. 167. o.).

Karácsony Sándor többé-kevésbé hasonló képet rajzol a debreceni református kollégiumról. Ő is szembeállítja az idősebb és a fiatalabb tanárok módszerét, stílusát. "Az öregek - nem is volt némelyiknek oklevele, «jogosított» tanár volt, lelkészi képesitéssel - úgy tanitottak és neveltek, ahogy Isten éppen tudniok engedte, szerfölött "cigányfülre». Kisebbik baj az, hogy az öregeket rajongva szerettük, és mai napig ellágyulva emlegetjük." "Az öreg debreceni tanárok emberek voltak. Szuszogtak, vicceltek, haragudtak, és latinul meg görögül tudtak." "Az egyik öregnek például szabad volt patáliát csapni, igazságtalan szekundákat beírni, pofonokat osztogatni történetesen ártatlanoknak valami félreértés miatt, amiröl kiderült, hogy ő tehet róla, nem mi. Óra végén az volt az osztály közvéleménye az esetröl, hogy bizonyosan két vastag harisnyát húzott, és nagyon szoritotta a cipője. Ezért is tudtunk nála, mert ezért is szerettük. Nagyon objektív és nagyon primitív módszer ez. Ember volt, mint mi. Ö tudott latinul, nekünk meg tanulnunk kellett latinul. Tőle lehetett, nekünk muszáj volt." (Karácsony, 1985. 438-441. o).

Ezzel szemben „a fiatalok módszeresen tanitottak. [...] a fiatalokat elviselhetetlen teherként hordoztuk, éspedig kivétel nélkül." "A fiatalok két lábon járó «nevelés-» és 
«tanítás»-absztrahálások voltak, nem is nagyon derült ki, tudnak-e, nem-e. Ök nem tudtak vagy nem-tudtak, hanem "tanítottak»". Ha az öreg tanár adott fel sok leckét, megtanulták, "ugyanakkor a fiatal tanár latinból csak 15 sort adott fel, és haragudtunk rá mégis" - irja Karácsony. A két csoport különbségének szummája: az öregek „„oszintén adták bele a közös munkába egész egyéniségüket." (Karácsony, 1985. 441. o.). Ez a gondolat Karácsony szemléletének az egyik kulcsa.

\section{ÉLMÉNYSZERŰSÉG}

A másik kulcs az élményszerúség. Karácsony az 1920-as évek elején szülővárosában, Földesen próbált olyan iskolát szervezni, amelyben érettségi bizonyítványt kaphatnak egyszerú parasztgyerekek, akik a gimnáziumi oktatásba nem kerülhettek be. Sok élményt adott neki ez a próbálkozás, és ô is az élményre helyezte a hangsúlyt. Például a helybeli gyerekek valamennyire tájékozódtak a csillagos égbolton, s erre alapozva magyarázta el, miért gömbölyú a Föld (Karácsony, 1994. 7-18. o).

Közismert Karácsony mély vallásossága is, és rendszeralkotó szemlélete. A magyar nyelvet az alárendeló szemléletú indoeurópai nyelvekkel szemben mellérendelőnek tartotta. Ilyennek látta a református egyház felépítését is: a lelkész és a presbitérium egymás mellett állva építi a gyülekezetet. A tanár-diák viszonyban az élményszerúség mellett a mellérendelésnek is érvényesülnie kell, vagyis az egymás iránti odaadó figyelemnek. Követői mélyen elköteleződtek iránta, a külvilág szerint szinte bálványozták őt. Sajnos kevés idő adatott számára: miután debreceni katedrájától megfosztották, 1952-ben elhunyt. Az új, állítólag „népi-demokratikus” hatalom nem tette lehetővé, hogy tanítványai megpróbálják megvalósítani Karácsony eszméit.

Ha közben az egyházra is pillantunk, itt is előkerült az élmény, vagyis a vallási élmény kérdése. A két világháború közötti időben a mai korhoz képest hatalmas tömeg járt vasárnaponként templomba, nagyrészt élt a hagyományos népi vallásosság. Az előbb említett, terjedőben lévő vallási közöny mellett viszont volt egy másik vissza-visszatérő kérdés: a kisegyházak, közismert (némileg lekicsinylő) szóval a szekták terjedése. Míg a hagyományos református vallási életre a kimért, mértéktartó, érzelemnyilvánítást kerüló szemlélet jellemző, addig ezek az új közösségek éppen a megtérés élményét hangsúlyozták és közösségeikben olyan otthonra lelhettek a hívek, amit a hagyományos egyházban nem találtak meg.

Hogyan fogta föl ezt a problémát a református teológia? Talán a legjobb válasz: távolságtartóan. Volt olyan vélemény, hogy a "szektákra" „tévelygo" és beteg vallásosság és torz hitigazságok" jellemzők (Sebestyén, 1997. 415. o.). Ehhez kapcsolódott az a vélemény, hogy a református egyházban nincs szükség vallási élményre. Még Karl Barth is így látta. Barth szemlélete az 1940-es évek elejétől szinte az 1990-es évekig meghatározó maradt, sokak szerint ő volt a XX. század legnagyobb református teológusa. Tavaszy Sándor Karl Barth-ot 
elemző tanulmányában kiemeli, a mester szerint az élmények helyett az alapos, rendszeres bibliaolvasásra kell törekedni (Tavaszy, 1997. 473-474. o). De olyan véleményt is olvashatunk (lehet, hogy Barth-tól függetlenül), hogy a megtérés egy észrevehetetlen folyamat. Sebestyén Jenő (1997. 247. o.) szerint „normális körülmények között nem megrázó belső forrongások útján kell az élö, öntudatos hitre, a megtéréshez eljutni, hanem valósággal lassan, észrevétlenül kell keresztyénné lennie, úgy, hogy bár a maga öntudatos keresztyénségéröl számot adni tud ugyan, de arról, hogy hogyan és mikor tért meg, nem."

1948-ban az egyházi iskolák államosításával a protestáns iskolai hagyomány megtört, csak a Debreceni Református Kollégium Gimnáziuma élte túl a Rákosiés Kádár-rendszert. Ezért is érdemes inkább emlékezetről, mint hagyományról beszélni a magyar protestáns iskolák esetében. Másrészt az 50-es évektől a megfélemlítés légkörében az istentiszteletek élményszerúsége is „lekerült a napirendről”: gyanússá vált a nagy hatású lelkész, sőt éppen jól végzett munkája miatt szenvedett hátrányt.

\section{KITEKINTÉS: AZ EZREDFORDULÓ UTÁNI HELYZET}

Az egyházi életben hellyel-közzel néhány dolog megváltozott. A középkori templomokban múemléki feltárással láthatóvá tették a középkori freskókat, így ezeken a helyeken a falak megszokott fehérsége megszúnt. (Legjobb példa éppen a Vizsolyi Biblia „szülőhelyén” emelkedő vizsolyi református templom lehetne.) A század végén egyes helyeken keresztet állítottak a templomban. Ma már előfordul, hogy a lelkész prezentációval színesíti a prédikációt. Mindezek azt mutatják: a hagyomány nem statikus. Az értelmező közösség változtatja annak elemeit.

Mi legyen az élményekkel az iskolákban? Mint az közismert, éppen Karácsonnyal egy időben jelentkezett a nyugati világban az élménypedagógia. Természetes, hogy egyházi iskolákban is ott a helye. A hitoktatásban még inkább használni kell módszereit.

Van viszont egy terület, ahol az egyházi iskola és az új pedagógiai módszerek, például a kooperatív tanulás szembekerülhet egymással. Ez a frontális tanítás kérdése. A frontális tanítás nemcsak azért korszerútlen, amiért a régebbi, 1960-80-as évekbeli szakirodalom annak tartja, hanem új világunk sajátosságai miatt is. A gyerekek egyre fiatalabb korban kapnak mobiltelefont, tabletet; ennek búvöletében élik életüket. Ha az eszközök miatt a figyelemhiány erősödik, jó gyógyírnak kínálkoznak a kooperatív tanulás módszerei. De mi lesz a templomban a prédikációval, ami a befogadó szempontjából hasonló a frontálisan tartott óra követésével? A protestáns egyházakban a prédikáció az istentisztelet központi eleme, akár húsz perces is lehet. Lehet vetítéssel színesíteni, ezzel enyhül a megértés gondja, de vajon megoldódik-e?

Itt most csak arra látok lehetőséget, hogy egy megértés-befogadásközpontú pedagógia lehetőségét vessem fel. A megértés az üzenetek türelmes feldolgozá- 
sát jelentené - érkezzen az üzenet egy másik gyerektől, vagy a szülőtől, vagy a tanártól. A napjainkban népszerú pedagógiai elgondolás szerint a tanulási és innovációs készségek fejlesztése során magyar fordításban négy K-ra kell figyelnünk: kreativitás, kooperáció, kommunikáció, kritikus gondolkodás

A kritikus gondolkodásnál érdemes lenne a megértésre törekvést jobban hangsúlyozni, az említett üzenetekre figyelés készségét rendszeresen fejleszteni. A megértés ugyanis nem elfogadás, önfeladás, van benne kritikai attitúd. De ha egyházi iskolákról van szó, akkor a Ricoeur és Lacocque (2003. 213-214. o) említette szeretô engedelmesség fogalmat is beilleszthetnénk ebbe a sémába.

\section{FELHASZNÁLT IRODALOM}

Assmann, Jan (2004): A kulturális emlékezet. Atlantisz Kiadó, Budapest.

Bitskey István (2007): „Nemúgy bátya!” Marginálisok Pázmány Kalauzában. In: Jankovics József (főszerk.): „Nem súlyed az emberiség!”... Album amicorum Szörényi László LX. születésnapjára. MTA Irodalomtudományi Intézet Budapest. Letöltés helye: http:/ / www.iti.mta.hu/szorenyi60.html Letöltés ideje: 2018.01.24.

Horváth Erzsébet (2014): A református iskolák államosítása Magyarországon (1945-1948). Magyarországi Református Egyház Zsinati Levéltára, Budapest. Letöltés: http://zsinatileveltar.hu/files/a_reformatus_iskolak_allam ositasa.pdf, 2018.01.24.

Kagan, Spencer és Kagan, Miguel (2009): Kooperatív tanulás. Ökönet Kiadó, Budapest. Letöltés: http://kemeny-eger.sulinet.hu/public/doks/koopera tiv_tanulas.pdf, 2018.01.24.

Karácsony Sándor (1985): Magyar észjárás. Magvető Kiadó, Budapest.

Karácsony Sándor (1994): Kísérleti parasztgimnázium Földesen, az 1919-20. tanévben. In: Hatvany László (szerk.): Karácsony Sándor pedagógiai írásaiból. 9 tanulmány, 1922-1946. Csökmei Kör, Pécel.

Karácsony Sándor (2004): A magyarok Istene. Széphalom Könyvmúhely, Budapest.

Móricz Zsigmond (1921): Légy jó mindhalálig. Athaeneum Kiadó, Budapest.

Németh András (2004): A magyar pedagógia tudománytörténete. Nemzetközi tudományfejlődési és recepciós hatások, nemzeti sajátosságok. Gondolat Kiadó, Budapest.

Nora, Pierre (2010): Emlékezet és történelem között. Válogatott tanulmányok. Napvilág Kiadó, Budapest.

Ricoeur, Paul és Lacocque, André (2003): Bibliai gondolkodás. Európa Kiadó, Budapest.

Sebestyén Jenő (1997): A református ember theologiai múveltsége. In: Németh Pál (szerk.): Magyar református önismereti olvasókönyv. Válogatás a XX. század első felének református teológiai irodalmából. Kálvin Kiadó, Budapest. 
Pedagógiatörténeti Szemle • 3. évf. 1-2. sz. 56-64. o. • 2017 DOI:10.22309/PTSZEMLE.2017.1.4

Szabó Magda (1980): Kívül a körön. Szépirodalmi Könyvkiadó, Budapest. Letöltés: http://dia.pool.pim.hu/xhtml/szabo_magda/Szabo_Magda-Kivul _a_koron.xhtml, 2018.01.24.

Tavaszy Sándor (1997): Barth, a teológus. In: Németh Pál (szerk.): Magyar református önismereti olvasókönyv. Válogatás a XX. század elsö felének református teológiai irodalmából. Kálvin Kiadó, Budapest.

White, Hayden (1997): A történelmi cselekményesítés és az igazság problémája In: A történelem terhe (összeáll. Braun Róbert). Osiris Kiadó, Budapest. 